\title{
Effects of sheep/goat whey protein dietary supplementation on the redox status of rats
}

\author{
EFTHALIA KERASIOTI ${ }^{1}$, DIMITRIOS STAGOS ${ }^{1}$, ARISTIDES M. TSATSAKIS ${ }^{2}$, DEMETRIOS A. SPANDIDOS ${ }^{3}$, \\ IOANNIS TAITZOGLOU ${ }^{4}$ and DEMETRIOS KOURETAS ${ }^{1}$
}

\author{
${ }^{1}$ Department of Biochemistry and Biotechnology, University of Thessaly, 41500 Larissa; ${ }^{2}$ Department of Forensic Sciences \\ and Toxicology, Medical School, University of Crete, 71409 Heraklion; ${ }^{3}$ Laboratory of Clinical Virology, \\ Medical School, University of Crete, 71003 Heraklion; ${ }^{4}$ School of Veterinary Medicine, \\ Aristotle University of Thessaloniki, 54124 Thessaloniki, Greece
}

Received January 19, 2018; Accepted February 20, 2018

DOI: $10.3892 / \mathrm{mmr} .2018 .8622$

\begin{abstract}
The purpose of the present study is to estimate the effects of sheep/goat whey protein dietary supplementation on the redox status of blood and tissues of rats. Twelve male Wistar rats were divided into the control group (standard commercial diet) and whey group [standard commercial diet + sheep/goat whey protein ( $1 \mathrm{~g} \mathrm{~kg} \mathrm{b.w/day)]} \mathrm{(6} \mathrm{rats/group).}$ The animals were maintainted on their respective diet for 28 days. At the end of the experimental period, reduced glutathione, catalase activity, total antioxidant capacity, thiobarbituric reactive substances, protein carbonyls and the decomposition rate of $\mathrm{H}_{2} \mathrm{O}_{2}$ were measured in blood and tissues of rats. According to the results, the rats fed with the sheep/goat whey protein exhibited improved antioxidant status and decreased free radical-induced toxic effects on lipids and proteins. Specifically, in blood, GSH and CAT levels were significantly increased while TBARS and protein carbonyl levels were significantly decreased compared to the control group. Regarding the effects on tissues, it was observed that GSH levels were significantly increased in small intestine,
\end{abstract}

Correspondence to: Professor Demetrios Kouretas, Department of Biochemistry and Biotechnology, University of Thessaly, Viopolis, Mezourlo, 41500 Larissa, Greece

E-mail:dkouret@uth.gr

Abbreviations: ARE, antioxidant response element; CAT, catalase; DNPH, 2,4-dinitrophenylhydrazine; DPPH, 2,2-diphenyl-1-picryl hydrazyl; DTNB, 5,5'-dithiobis (2-nitrobenzoic acid); ERKs, extracellular signal-regulated kinases; GCL, glutamate cysteine ligase; GPx, glutathione peroxidase; GS, glutathione synthetase; GSH, glutathione; GST, glutathione-s-transferase; $\mathrm{H}_{2} \mathrm{O}_{2}$, hydrogen peroxide; HCL, hydrochloride; JNKs, c-Jun N-terminal kinases; Keap1, Kelch-like ECH-associated protein 1; Nrf2, nuclear factor E2-related factor 2; $\mathrm{OH}$, hydroxyl radical; PBS, phosphate-buffered saline; TAC, total antioxidant capacity; TBARS, thiobarbituric reactive substances; TAC, trichloroacetic acid; Tris, trishydroxymethylaminomethane

Key words: sheep/goat whey protein, redox status, glutathione, catalase, lipid oxidation, protein oxidation quadriceps muscle, pancreas and lung tissue compared to the control group. The decomposition rate of $\mathrm{H}_{2} \mathrm{O}_{2}$ was significantly decreased in liver, brain and quadriceps muscle, but was significantly increased in spleen tissue compared to the control group. TBARS levels were significantly decreased in liver, brain, quadriceps muscle, pancreas, lung and spleen tissue compared to the control group. Finally, protein carbonyl levels were significantly decreased in brain, small intestine, kidney, pancreas and spleen tissue compared to the control group. Thus, the present findings show the beneficial effects of sheep/goat whey protein, a by-product of cheese manufacturing, on the redox status in an in vivo model.

\section{Introduction}

Milk components have been recognized as functional foods, with positive health effects (1). Milk proteins are available as whole milk proteins, caseinates, and whey proteins. Whey protein is a high quality protein that contains higher amounts of essential amino acids in comparison with other sources of protein, such as egg and soy (2).

Whey, a by-product of cheese manufacturing, has been considered for a long time a waste product. Its discharge to the environment and the improper management and exploitation causes important environmental problems (3). The discovery of whey as a functional food with nutritional applications, raised its status to co-product in cheese production (2). The composition of whey depends mainly on the type of cheese and milk, on the lactation phase and on its processing. Whey is a mixture of proteins, such as $\alpha$-lactalbumin, $\beta$-galactoglobulin, serum albumin, immunoglobulins, lactoferrin, and galactoperoxidase with various chemical, physical and functional properties $(4,5)$. Whey protein, not only plays an important role in nutrition, as it is a rich and balance source of amino acids, but in some cases also exhibits specific physiological activity in vivo (6). Furthermore, whey protein exhibits antioxidant activity probably due to its rich content in cysteines, which promotes glutathione (GSH) synthesis, an important intracellular antioxidant (2). It is therefore a potentially important tool for the treatment of oxidative stress-associated diseases. 
In previous studies of our laboratory, we examined the possible antioxidant activity of sheep/goat whey protein in vitro. Firstly, it was found that sheep/goat whey protein has the ability to neutralize free radicals and consequently protect biomolecules from oxidative damage (7). Furthermore, sheep/goat whey protein exerts a protective effect against oxidative stress in muscle (C2C12) and endothelial (Ea.hy926) cells $(7,8)$. Finally, in Ea.hy926 cells, it has been found that a number of antioxidant enzymes were activated through the nuclear factor E2-related factor 2 (Nrf2)-antioxidant response element (ARE) pathway. In $\mathrm{C} 2 \mathrm{C} 12$ cells, activation of the antioxidant enzymes was not dependent on the Nrf2-ARE pathway (9). In an in vivo study in athletes, the combination of whey proteins with carbohydrates reduced lipid peroxidation and exerted anti-inflammatory action $(10,11)$.

Considering the above beneficial effects of sheep/goat whey protein against oxidative stress and the growing need for biofunctional foods with health claims, it would be of great interest to study the effects of sheep/goat whey protein on a living organism at blood and tissue level. Notably, the studies concerning the biological activity of sheep/goat whey protein are limited and the majority concerns bovine whey protein. Thus, the aim of the present study is to evaluate the antioxidant activity of sheep/goat whey protein in vivo. Specifically, it will determine a number of redox status markers in blood and tissues of rats after the administration of sheep/goat whey protein.

\section{Materials and methods}

Chemicals. Hydrogen peroxide $\left(\mathrm{H}_{2} \mathrm{O}_{2}\right) 30 \%$, 5,5'-dithiobis (2-nitrobenzoic acid) (DTNB), 2,4-dinitrophenylhydrazine (DNPH), 2,2-diphenyl-1-picryl hydrazyl (DPPH), urea, sodium sulfate and Bradford reagent were purchased from Sigma-Aldrich (St. Louis, MO, USA). Sodium citrate was purchased from Merck KGaA (Darmstadt, Germany). Protease inhibitor coctail tablets were supplied from Roche Diagnostics (Indianapolis, IN, USA). Phosphate-buffered saline (PBS) was purchased from Gibco; Thermo Fisher Scientific, Inc. (Waltham, MA, USA).

Materials. Sheep/goat whey protein was obtained from the Hellenic Protein S.A (Athens, Greece) and its content was $80 / 100 \mathrm{~g}$. In Table I, the nutritional content and the profile fraction of sheep/goat whey protein are presented.

Experimental animals. Twelve male Wistar rats (6-month-old) with an average body weight of $470 \mathrm{~g}$ were used in the experiments under the frame of an animal experiment performed in the animal facilities of the Veterinary Medicine School of Aristotle University of Thessaloniki and licenced by the National Veterinary Administration authorities. All the animals received human care according to the Helsinki Declaration and national standards. Animals were housed in individual cages in a room with controlled temperature (20-22 $\left.{ }^{\circ} \mathrm{C}\right)$ and humidity conditions and a 12-h light/dark cycle.

Experimental design. Animals were divided into 2 groups (6 rats/group) and were maintained on their respective diet for 28 days as follows: Control group $(n=6)$; fed with standard commercial diet (corn, soybean meal, barley, bran, milk paste,
Table I. Nutritional content and profile fraction of sheep/goat whey protein.

Nutritional content (per $100 \mathrm{~g}$ ).

\begin{tabular}{lc}
\hline Items & Sheep/goat whey protein \\
\hline Energy & $396 \mathrm{kcal} / 1678 \mathrm{~kJ}$ \\
Proteins & $80 \mathrm{~g}$ \\
Carbohydrates & $10 \mathrm{~g}$ \\
Fats & $4 \mathrm{~g}$ \\
Sodium & $157 \mathrm{mg}$ \\
Potassium & $397 \mathrm{mg}$ \\
Calcium & $415 \mathrm{mg}$ \\
Phosphorus & $319 \mathrm{mg}$ \\
Magnesium & $73 \mathrm{mg}$ \\
\hline
\end{tabular}

Profile fraction (per $100 \mathrm{~g}$ ).

Protein mixture Sheep/goat whey protein

\begin{tabular}{lr}
\hline$\beta$-lactoglobulin & $47 \mathrm{~g}$ \\
$\alpha$-lactalbumin & $14 \mathrm{~g}$ \\
Glycomacropeptide & $13 \mathrm{~g}$ \\
Serum albumin & $3 \mathrm{~g}$ \\
\hline
\end{tabular}

molasses) purchased from Viozois S.A. (Ioannina, Greece), and the experimental group $(n=6)$; fed with standard commercial diet plus sheep/goat whey protein ( $1 \mathrm{~g} / \mathrm{kg}$ body weight/day) dissolved in drinking water. The animals were observed daily for general health and body weight was measured at the beginning and at the end of the experimental period. At the end of the treatment period, the animals were anaesthetized with diethyl ether and blood samples were drawn by cardiac puncture. The animals were euthanized by decapitation under deep anaesthesia. Tissues from liver, spleen, pancreas, brain, heart, quadriceps muscle, lung, small intestine and kidney were excised, snap-frozen in liquid nitrogen and stored at $-80^{\circ} \mathrm{C}$ until analysis. The experimental design is described in Fig. 1.

Blood preparation. Blood samples were centrifuged immediately at $1,370 \mathrm{x}$ for $10 \mathrm{~min}$ at $4^{\circ} \mathrm{C}$ and the plasma was collected and used for the measurement of total antioxidant capacity (TAC), thiobarbituric reactive substances (TBARS) and protein carbonyls. The packed erythrocytes were lysed with distilled water $(1: 1 \mathrm{v} / \mathrm{v})$, inverted vigorously, centrifuged at $4,000 \mathrm{x} \mathrm{g}$ for $15 \mathrm{~min}$ at $4^{\circ} \mathrm{C}$ and the erythrocyte lysate was collected for the measurement of GSH and catalase (CAT) activity. Plasma and erythrocyte lysate were stored at $-20^{\circ} \mathrm{C}$ until analysis.

Preparation of tissue homogenates. Tissue samples were thawed at $37^{\circ} \mathrm{C}$ and homogenized in PBS (0.01 M, pH 7.4) containing a cocktail of protease inhibitors (Complete ${ }^{\mathrm{TM}}$ mini protease inhibitors). Brief sonication $(3 \times 10 \mathrm{sec})$ on ice followed for better homogenization. The homogenate was then centrifuged at $10,000 \times \mathrm{g}$ for $15 \mathrm{~min}$ at $4^{\circ} \mathrm{C}$, the supernatant 

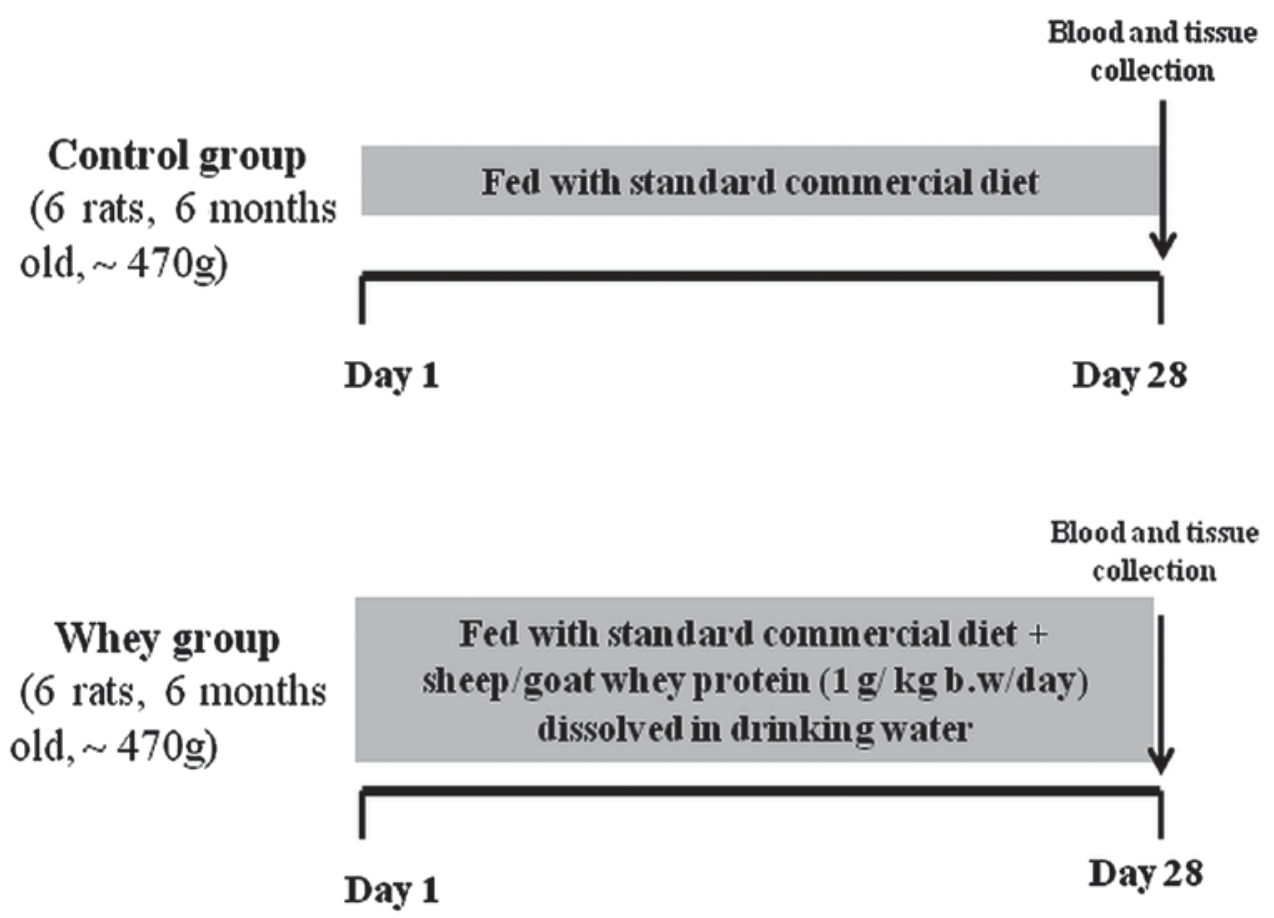

Figure 1. Experimental design to study the effects of sheep/goat whey protein on the redox status of blood and tissues in rats. Animals were maintained on their respective diet for 28 days. The arrow symbolizes the experiment completion and blood/tissue collection.

was collected and the protein concentration was measured using the Bradford method. Samples were stored at $-80^{\circ} \mathrm{C}$ until biochemical analysis.

Assays. GSH was measured according to a slightly modified method of Reddy et al (12), as described by Spanidis et al (13). A total of $20 \mu \mathrm{l}$ of erythrocyte lysate or $400 \mu \mathrm{g}$ of tissue homogenate was processed with $5 \%$ trichloroacetic acid (TCA), mixed with $660 \mu \mathrm{l}$ of $67 \mathrm{mM}$ sodium potassium phosphate (pH 8) and $330 \mu \mathrm{l}$ of $1 \mathrm{mM}$ DTNB. The samples were incubated in the dark at room temperature for $15 \mathrm{~min}$ and the absorbance was read at $412 \mathrm{~nm}$. GSH concentration was calculated on the basis of a calibration curve made using commercial standards.

CAT activity in erythrocytes and the rate of $\mathrm{H}_{2} \mathrm{O}_{2}$ decomposition were determined as previously described by Spanidis et al (13), a slightly modified method of Aebi (14). Briefly, $4 \mu \mathrm{l}$ of erythrocyte lysate (diluted 1:10) or $400 \mu \mathrm{g}$ of tissue homogenate were added to $2,991 \mu \mathrm{l}$ of $67 \mathrm{mM}$ sodium potassium phosphate $(\mathrm{pH} 7.4)$ and the samples were incubated at $37^{\circ} \mathrm{C}$ for $10 \mathrm{~min}$. Five microliters of $30 \% \mathrm{H}_{2} \mathrm{O}_{2}$ were added to the samples and the change in absorbance was immediately read at $240 \mathrm{~nm}$ for $130 \mathrm{sec}$. Calculation of CAT activity was based on the molar extinction coefficient of $\mathrm{H}_{2} \mathrm{O}_{2}$.

The determination of TAC was based on the method of Janaszewska and Bartosz (15) with slight modifications as previously described by Spanidis et al (13). Briefly, $20 \mu \mathrm{l}$ of plasma or $400 \mu \mathrm{g}$ of tissue homogenate were added to $480 \mu \mathrm{l}$ of $10 \mathrm{mM}$ sodium potassium phosphate ( $\mathrm{pH} 7.4)$ and $500 \mu \mathrm{l}$ of $0.1 \mathrm{mM} \mathrm{DPPH}^{\circ}$ free radical and the samples were incubated in the dark for $60 \mathrm{~min}$ at room temperature. The samples were centrifuged at $20,000 \mathrm{x}$ f for $3 \mathrm{~min}$ and the absorbance was read at $520 \mathrm{~nm}$. TAC was presented as mmol of $\mathrm{DPPH}^{\circ}$ reduced to 2,2-diphenyl-1-picrylhydrazine (DPPH:H) by the antioxidants of plasma.

For TBARS determination, a slightly modified assay of Keles et al (16) was used as per the protocol used in Spanidis et al (13). According to this method, $100 \mu 1$ of plasma or $400 \mu \mathrm{g}$ of tissue homogenate was mixed with $500 \mu \mathrm{l}$ of $35 \%$ TCA and $500 \mu \mathrm{l}$ of Tris- $\mathrm{HCl}(200 \mathrm{mM}, \mathrm{pH}$ 7.4). Incubation for $10 \mathrm{~min}$ at room temperature followed. Then, $1 \mathrm{ml}$ of $2 \mathrm{M}$ $\mathrm{Na}_{2} \mathrm{SO}_{4}$ and $55 \mathrm{mM}$ thiobarbituric acid solution was added and the samples were incubated at $95^{\circ} \mathrm{C}$ for $45 \mathrm{~min}$. The samples were cooled on ice for $5 \mathrm{~min}$, followed by the addition of $1 \mathrm{ml}$ of $70 \%$ TCA and then the samples were vortexed. The samples were centrifuged at $15,000 \mathrm{x}$ g for $3 \mathrm{~min}$ and the absorbance of the supernatant was read at $530 \mathrm{~nm}$. Calculation of TBARS concentration was based on the molar extinction coefficient of malondialdehyde.

Protein carbonyl determination was based on a slightly modified method of Patsoukis et al (17), as previously described by Spanidis et al (13). Briefly, $50 \mu \mathrm{l}$ of $20 \%$ TCA were added to $50 \mu \mathrm{l}$ of plasma or to $400 \mu \mathrm{g}$ of tissue homogenate and this mixture was incubated in an ice bath for $15 \mathrm{~min}$ and centrifuged at $15,000 \mathrm{x} \mathrm{g}$ for $5 \mathrm{~min}$ at $4^{\circ} \mathrm{C}$. The supernatant was discarded and $500 \mu \mathrm{l}$ of $10 \mathrm{mM}$ DNPH (in $2.5 \mathrm{~N} \mathrm{HCl}$ ) for the sample, or $500 \mu \mathrm{l}$ of $2.5 \mathrm{~N} \mathrm{HCl}$ for the blank, were added in the pellet. The samples were incubated in the dark at room temperature for $1 \mathrm{~h}$, with vortexing every $15 \mathrm{~min}$, followed by centrifugation at $15,000 \mathrm{x} \mathrm{g}$ for $5 \mathrm{~min}$ at $4^{\circ} \mathrm{C}$. The supernatant was discarded and $1 \mathrm{ml}$ of $10 \%$ TCA was added, vortexed and centrifuged at $15,000 \mathrm{x} \mathrm{g}$ for $5 \mathrm{~min}$ at $4^{\circ} \mathrm{C}$. The supernatant was again discarded and $1 \mathrm{ml}$ of ethanol-ethyl acetate (1:1 v/v) was added, vortexed and centrifuged at $15,000 \times \mathrm{g}$ for $5 \mathrm{~min}$ at $4^{\circ} \mathrm{C}$. This step was repeated twice. The supernatant was discarded and $1 \mathrm{ml}$ of $5 \mathrm{M}$ urea ( $\mathrm{pH}$ 2.3) was added, vortexed and incubated 


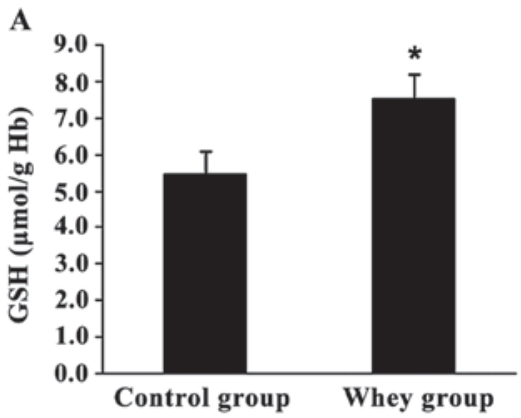

C

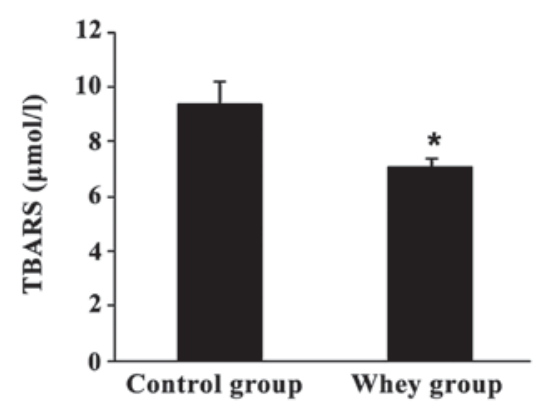

B

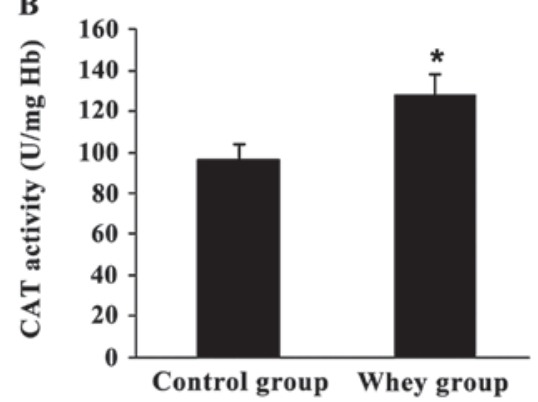

D

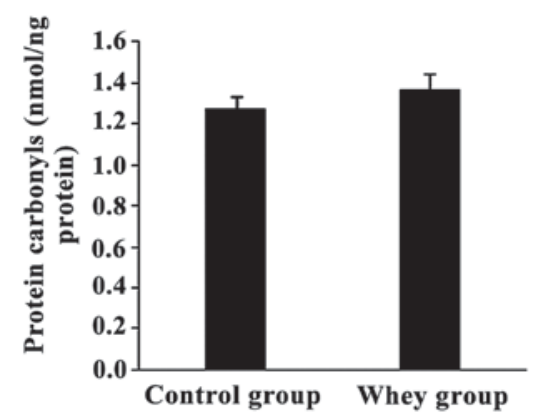

$\mathbf{E}$

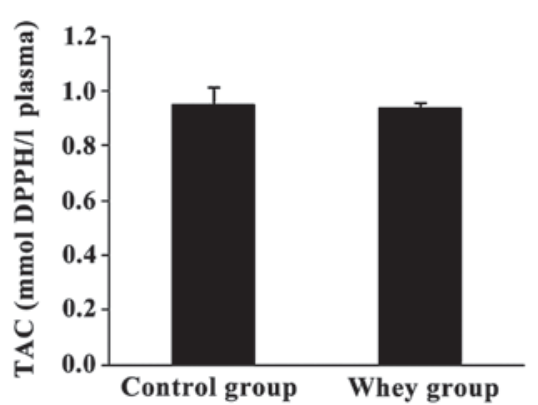

Figure 2. Effects of sheep/goat whey protein on redox status markers of blood. (A) GSH, (B) CAT, (C) TBARS, (D) protein carbonyls and (E) TAC levels in blood of rats in control and whey group. ${ }^{*} \mathrm{P}<0.05$; statistically significant compared to the control group. All results are presented as mean $\pm \mathrm{SEM}$. GSH, glutathione; CAT, catalase; TBARS, thiobarbituric reactive substances; TAC, total antioxidant capacity.

at $37^{\circ} \mathrm{C}$ for $15 \mathrm{~min}$. The samples were centrifuged at $15,000 \mathrm{x} \mathrm{g}$ for $3 \mathrm{~min}$ at $4^{\circ} \mathrm{C}$ and the absorbance was read at $375 \mathrm{~nm}$. Calculation of protein carbonyl concentration was based on the molar extinction coefficient of DNPH.

Statistical analysis. For the statistical analysis, one-way ANOVA followed by Tukey's test was applied to compare the means between the two groups ( $n=6$ per group). Differences were considered significant at $\mathrm{P}<0.05$ with $\alpha$ level set at 0.025 . The results are expressed as mean \pm SEM. Statistical analyses were performed using the SPSS software (version 14.0; SPSS, Inc., Chicago, IL, USA).

\section{Results}

Assessment of redox status markers in rats' blood. Fig. 2 shows the effects of sheep/goat whey protein on the redox status of rats in blood. Oxidative stress markers measured in blood showed that sheep/goat whey protein improved the redox status of rats.

Specifically, GSH levels and CAT activity in erythrocyte lysate were increased significantly by $37.6 \%(\mathrm{P}=0.047)$ and
$32.2 \%(\mathrm{P}=0.041)$, respectively, in the sheep/goat whey protein group compared to the control group (Fig. 2A and B).

TBARS levels in plasma were significantly decreased by $24.5 \%(\mathrm{P}=0.033)$ in the sheep/goat whey protein group compared to the control group (Fig. 2C).

Finally, there was not any significant change in protein carbonyl levels and TAC in plasma between the sheep/goat whey protein and control groups (Fig. 2D and E).

Assessment of redox status markers in tissues of rats. The administration of sheep/goat whey protein increased significantly the GSH levels in small intestine, quadriceps muscle, pancreas and lung by $37.8 \%(\mathrm{P}=0.032), 34.7 \%(\mathrm{P}=0.044), 78 \%$ $(\mathrm{P}=0.013)$ and $172 \%(\mathrm{P}=0.004)$, respectively, compared to the control group (Fig. 3A and $\mathrm{B}$ ).

The rate of $\mathrm{H}_{2} \mathrm{O}_{2}$ decomposition was decreased significantly in liver, brain and quadriceps muscle by $22.7 \%(\mathrm{P}=0.012)$, $23.5 \%(\mathrm{P}=0.042), 47.2 \%(\mathrm{P}=0.048)$ respectively in sheep/goat whey protein group compared to control group (Fig. 3A). In spleen, the rate of $\mathrm{H}_{2} \mathrm{O}_{2}$ decomposition was increased significantly by $21.3 \%(\mathrm{P}=0.009)$ in sheep/goat WP group compared to control group (Fig. 3B). 

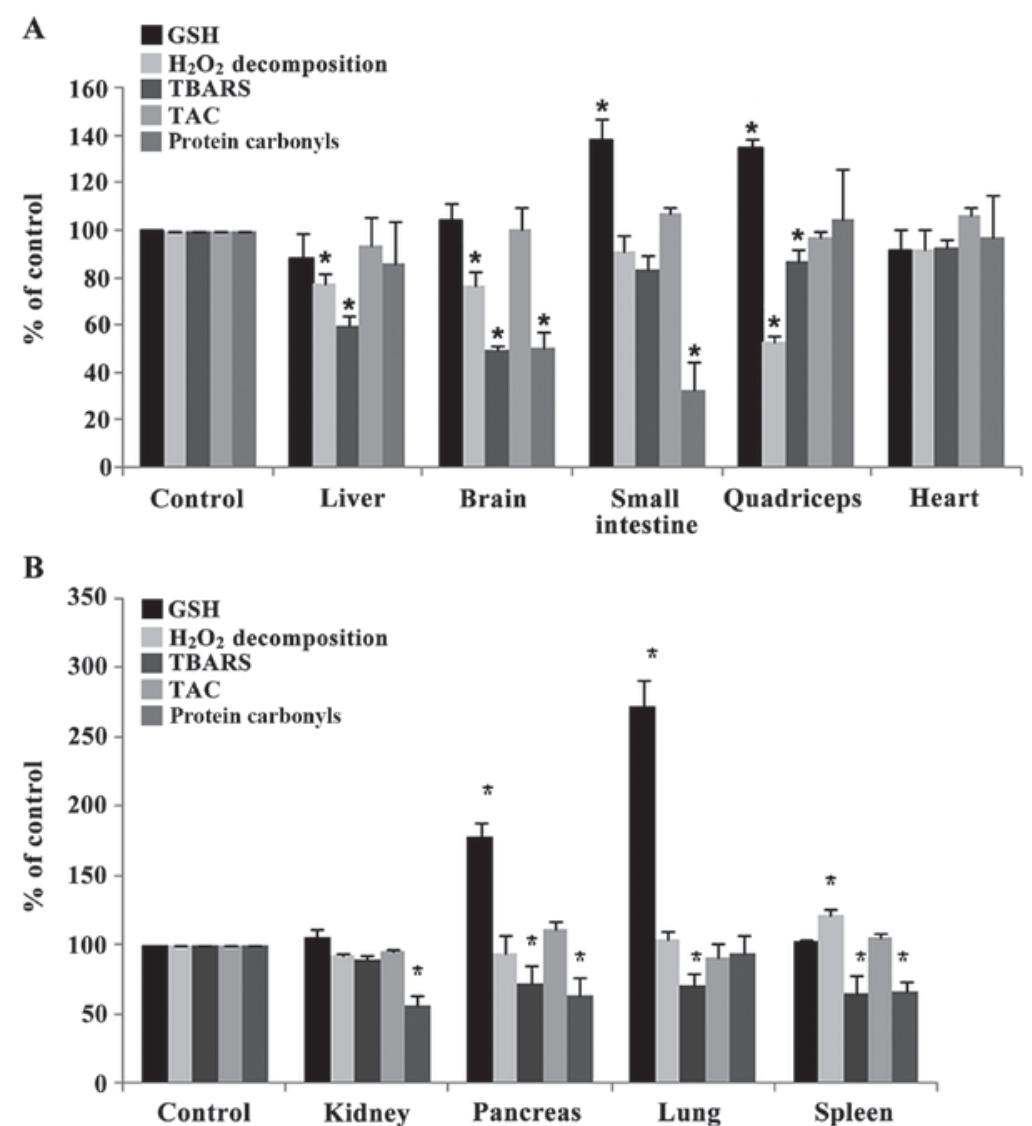

Figure 3. Effects of sheep/goat whey protein on redox status markers of tissues. (A) GSH, $\mathrm{H}_{2} \mathrm{O}_{2}$ decomposition, TBARS, TAC, protein carbonyls levels in liver, brain, small intestine, quadriceps and heart of rats in the control and whey groups. (B) GSH, $\mathrm{H}_{2} \mathrm{O}_{2}$ decomposition, TBARS, TAC, protein carbonyls levels in kidney, pancreas, lung and spleen of rats in control and whey group. "P $<0.05$; statistically significant compared to control group. Results are presented as mean \pm SEM. GSH, glutathione; TBARS, thiobarbituric reactive substances; TAC, total antioxidant capacity.

TBARS levels were decreased significantly in liver, brain, quadriceps muscle, pancreas, lung and spleen by 40.5\% ( $\mathrm{P}=0.006), 50.6 \%(\mathrm{P}=0.000), 12.9 \%(\mathrm{P}=0.005), 27.6 \%$ $(\mathrm{P}=0.031), 28.9 \%(\mathrm{P}=0.031)$ and $36 \%(\mathrm{P}=0.017)$, respectively, in the sheep/goat whey protein group compared to the control group (Fig.3A and B).

Regarding protein carbonyl levels, there was a significant decrease in brain, small intestine, kidney, pancreas and spleen by 50\% ( $\mathrm{P}=0.002), 67.7 \%(\mathrm{P}=0.032), 44 \%(\mathrm{P}=0.009)$, $37.3 \%(\mathrm{P}=0.045)$ and $33.7 \%(\mathrm{P}=0.018)$, respectively, in the sheep/goat whey protein group compared to the control group (Fig. 3A and B).

Finally, TAC levels were not affected by the administration of sheep/goat whey protein in any tissue (Fig. 3A and B).

\section{Discussion}

In recent years, there has been an increased interest regarding the intake of natural products in order to prevent oxidative damage caused by free radicals (18-22). When the production of free radicals is increased to an extent that cannot be coped by the organisms' antioxidant mechanisms, oxidative stress is induced (23). This results in irreversible damage, not only to cellular structure and function, but also to vital organs. Exposure to high levels of free radicals can cause lipid and protein oxidation and also damage to DNA $(24,25)$. Oxidative damage of biomolecules (lipids, proteins, DNA) is one of the main factors in the process of aging and in various diseases such as carcinogenesis, cardiovascular diseases, neurodegenerative diseases, atherosclerosis, diabetes and asthma (26-29).

The discovery of whey as a functional food increased its status as a co-product in cheese production (2). Whey protein is a rich and balanced source of sulfur-containing amino acids (cysteine, methionine). These amino acids enhance antioxidant defense either by acting directly as reducing agents or as precursors of the intracellular formation of GSH (30).

In the present in vivo study, we evaluated the effects of sheep/goat whey protein on the redox status of rats. Specifically, we estimated the levels of five redox status markers (GSH,CAT, TBARS, protein carbonyls, TAC) in blood and tissues. GSH is the most rich non-protein source of thiol (SH) in cells. GSH is important to a variety of processes, including the detoxification of xenobiotics, maintenance of the -SH level of proteins and scavenging of hydroperoxides and free radicals (31). CAT is an antioxidant enzyme that is present in every cell type and especially in peroxisomes and catalyzes the conversion of $\mathrm{H}_{2} \mathrm{O}_{2}$ to water and molecular oxygen (32). TBARS and protein carbonyls are markers of lipid and protein oxidation, respectively. Finally, TAC is referred to the capability of the plasma components to scavenge reactive species and is an indicator of the overall antioxidant capacity of plasma.

Specifically, it was found that GSH levels were significantly increased in erythrocytes, small intestine, quadriceps muscle, pancreas and lung tissues compared to the control. 


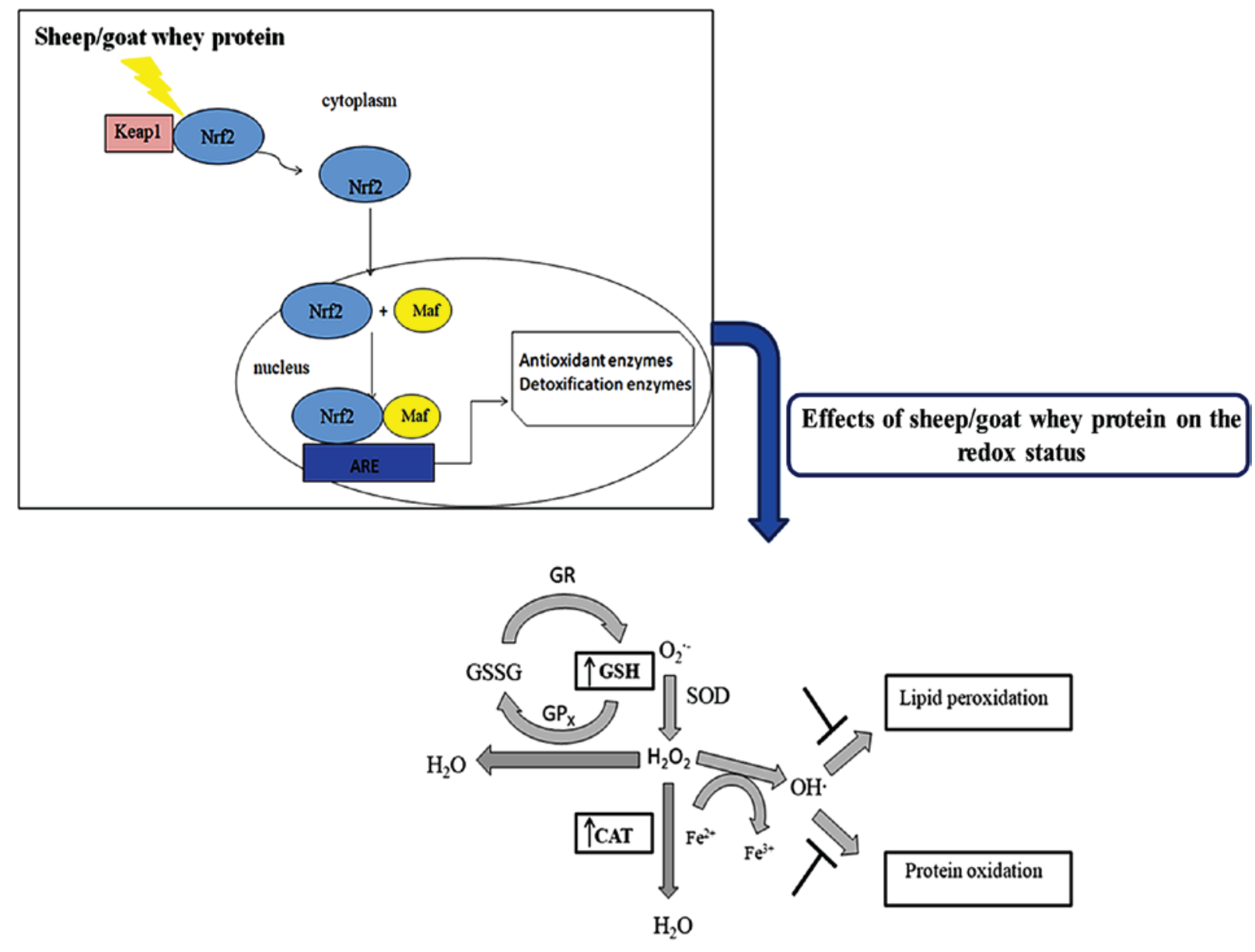

Figure 4. Possible mechanism by which sheep/goat whey protein exerts its effects.

According to the literature, it has also been found that whey protein enhances antioxidant capacity in rats through GSH synthesis. In particular, whey protein enhanced GSH synthesis in erythrocytes in rats by $31 \%$ (33). Other findings showed that treatment with whey protein enhanced total liver GSH content in rats (34). GSH is the most important antioxidant in cells and offers protection against oxidative damage caused by free radicals, peroxides and heavy metals. The increased levels of GSH may be attributed to the rich content of whey in cysteine and methionine. These amino acids are precursors for the intracellular conversion of GSH (30). Whey may also increase GSH levels through modulation of the two key enzymes that are involved in its biosynthesis; glutamate cysteine ligase (GCL) and glutathione synthetase (GS). In previous studies, it has been shown that sheep/goat whey protein increased GCL expression in $\mathrm{C} 2 \mathrm{C} 12$ muscle cells (9). A possible mechanism, through which the expression of these enzymes is regulated, may be the cytosolic system Nrf2-Kelch-like ECH-associated protein 1 (Keap1). In endothelial cells it has been found that the expression of a number of antioxidant enzymes is regulated through Nrf2-Keap1 pathway (9). Under normal conditions, Nrf2 is located in the cytoplasm anchored by Keap1 resulting in its ubiquitination and proteasome degradation. The activation of Nrf2 is regulated by two signaling pathways: i) Oxidation of Keap1s' cysteine residues; and/or ii) activation of a number of protein kinases that induce phosphorylation of Nrf2. Both facilitate the disassociation from Keap1 and its translocation in the nucleus. The nuclear Nrf2 binds to the ARE and induces the activation of a number of antioxidant enzymes or phase II metabolism enzymes (35-38). It has been found that whey protein can activate c-Jun N-terminal kinases (JNKs) and extracellular signal-regulated kinases (ERKs) (39). Thus, sheep/goat whey protein may induce the phosphorylation of Nrf2, disassociation from Keap1, translocation in the nucleus and finally activation of antioxidant enzymes.

In erythrocytes, the conversion of $\mathrm{H}_{2} \mathrm{O}_{2}$ to $\mathrm{H}_{2} \mathrm{O}$ and $\mathrm{O}_{2}$ is based on CAT activity (40) while in tissues, the decomposition of $\mathrm{H}_{2} \mathrm{O}_{2}$ to $\mathrm{H}_{2} \mathrm{O}$ and $\mathrm{O}_{2}$ is attributed, not only to CAT activity, but also to other enzymes such as glutathione peroxidase (GPx) and peroxiredoxins (41). In erythrocytes, it was found that CAT activity was increased significantly compared to control. In liver, brain and quadriceps muscle tissues, the rate of $\mathrm{H}_{2} \mathrm{O}_{2}$ decomposition was decreased compared to the control group while in spleen tissue the decomposition rate was increased compared to the control. While we would expect sheep/goat whey protein to increase the rate of $\mathrm{H}_{2} \mathrm{O}_{2}$ decomposition, in some tissues a reduction is observed. This could be probably attributed to the activation of a different number of antioxidant enzymes and especially GSH-associated enzymes. Haraguchi et al (34) has shown that whey protein decreased liver CAT activity in rats. In previous studies, we have shown that CAT expression and activity was increased in $\mathrm{C} 2 \mathrm{C} 12$ muscle and Ea.hy926 endothelial cells (9). 
Concerning the effects of sheep/goat whey protein on lipid peroxidation in plasma, it has been found that TBARS was significantly decreased compared to the control group. The decrease in lipid peroxidation in plasma can be attributed to the respective increase in CAT activity and GSH synthesis. Concerning the tissues, we have observed that TBARS levels were significantly decreased in liver, brain, quadriceps muscle, pancreas, lung and spleen compared to the control group. Depending on the tissue, the decrease could be attributed either to GSH molecule and CAT enzyme or to the activation of a different number of antioxidant enzymes [GPx, glutathione-s-transferase (GST)]. GSH reduces $\mathrm{H}_{2} \mathrm{O}_{2}$ and organic peroxides through a GPx-catalyzed reaction, neutralizes hydroxyl radical $\left(\mathrm{OH}^{*}\right)$ and therefore prevents lipid peroxidation (42). The $\mathrm{OH}^{*}$ is one of the most reactive and dominant ROS that can initiate lipid peroxidation. In biological systems, $\mathrm{OH}^{*}$ is formed by Fenton-Haber-Weiss reactions where free iron $\left(\mathrm{Fe}^{2+}\right)$ reacts with $\mathrm{H}_{2} \mathrm{O}_{2}$ (43). Another enzyme that may prevent lipid peroxidation is GST through the conjugation of electrophilic compounds to GSH, leading to their elimination from the body (44). It has been found that sheep/goat whey protein increases GST activity in C2C12 muscle and Ea.hy926 endothelial cells (9). Thus, GSH and CAT can offer protection against lipid damage and its subsequent detrimental effects (destruction of the integrity of cell membranes, cell death).

Protein damage can cause loss of enzyme function, alter cellular activities and can also cause changes in the type and level of cellular proteins $(45,46)$. Oxidation of proteins and amino acids is accompanied by increases in the levels of protein carbonyl groups $(47,48)$. The results of the present study have shown that protein carbonyls were decreased in brain, small intestine, kidney, pancreas and spleen tissue compared to the control group. It is suggested that $\mathrm{OH}^{*}$ can also cause damage to proteins by reducing their disulfide bonds, resulting in their unfolding or misfolding (49). Thus, sheep/goat whey protein can protect both from protein and lipid peroxidation either by activating a number of antioxidant molecules and enzymes or by scavenging $\mathrm{OH}^{*}(7-9)$.

In conclusion, the findings of the present study have shown that sheep/goat whey protein protects against the detrimental effects of oxidative stress and enhances the antioxidant defense mechanisms in blood and tissues (Fig. 4). The results have shown a tissue-specific effect of sheep/goat whey protein. Taking this finding into account, we could lead to nutritional intervention strategies in order to prevent various oxidative stress-associated diseases. Considering the above beneficial effects of sheep/goat whey protein, the investigation of its molecular mechanism of action in order to be incorporated as a bioactive ingredient into food products would be of particular interest and importance. This could give additional value to sheep/goat whey protein contributing on one hand to its profitable utilization and on the other hand to addressing the environmental problems caused by its uncontrolled disposal.

\section{Acknowledgements}

I would like to thank $\mathrm{PhD}$ candidate Sotiria Makri and Dr Ioannis Kafantaris for their technical assistance.

\section{Funding}

The present study was supported in part by IKY Fellowships funded by the action 'Enhancement of Post-Doctoral Researchers' from the resources of the European Program 'Development of Human Resources, Education and Life-Long Learning' co-funded by the European Social Fund.

\section{Availability of data and materials}

The datasets used and/or analyzed during the current study are available from the corresponding author on reasonable request.

\section{Authors' contributions}

EK designed the experiment, analyzed and interpreted the data concerning the redox status. DS was involved in the design of the experiment. AMT and DAS contributed to the evaluation of the results and to the writing of the manuscript. IT provided the animal facility, took care of the animals and collected the blood and the tissues. DK was the supervisor of experiment, involved in the draft of the manuscript and gave the final approval of the manuscript to be published. All the authors read and approved the final manuscript.

\section{Ethics approval and consent to participate}

The animals received human care according to the Helsinki Declaration and national standards.

\section{Consent for publication}

Not applicable.

\section{Competing interests}

Demetrios A. Spandidos is the Editor-in-Chief for the journal, but had no personal involvement in the reviewing process, or any influence in terms of adjudicating on the final decision, for this article.

\section{References}

1. Gill HS, Rutherfurd-Markwick KJ and Cross ML: Bovine milk: A unique source of immunomodulatory ingredients for functional foods. In: Functional Foods II - Claims and Evidence. Saltmarsh M and Buttriss J (eds). Royal Society of Chemistry Press 248, Cambridge, pp82-90, 2000.

2. Walzem RL, Dillard CJ and German JB: Whey components: Millennia of evolution create functionalities for mammalian nutrition: What we know and what we may be overlooking. Crit Rev Food Sci Nutr 42: 353-375, 2002.

3. Smithers GW: Whey and whey proteins - from 'gutter-to-gold'. Int Dairy J 18: 695-704, 2008.

4. Farrell HM Jr, Jimenez-Flores R, Bleck GT, Brown EM, Butler JE, Creamer LK, Hicks CL, Hollar CM, Ng-Kwai-Hang KF and Swaisgood HE: Nomenclature of the proteins of cows' milk - sixth revision. J Dairy Sci 87: 1641-1674, 2004.

5. Mollea C, Marmo L and Bosco F: Valorisation of cheese whey, a by-product from the dairy industry. In: Food Industry. Muzzalupo I (ed). InTech, pp549-588, 2013.

6. Marshall K: Therapeutic applications of whey protein. Altern Med Rev 9: 136-156, 2004. 
7. Kerasioti E, Stagos D, Priftis A, Aivazidis S, Tsatsakis AM, Hayes AW and Kouretas D: Antioxidant effects of whey protein on muscle C2C12 cells. Food Chem 155: 271-278, 2014.

8. Kerasioti E, Stagos D, Georgatzi V, Bregou E, Priftis A, Kafantaris I and Kouretas D: Antioxidant effects of sheep whey protein on endothelial cells. Oxid Med Cell Lonqev 2016, 6585737, 2016.

9. Kerasioti E, Stagos D, Tzimi A and Kouretas D: Increase in antioxidant activity by sheep/goat whey protein through nuclear factor-like $2(\mathrm{Nrf} 2)$ is cell type dependent. Food Chem Toxicol 97: 47-56, 2016b.

10. Kerasioti E, Kiskini A, Veskoukis A, Jamurtas A, Tsitsimpikou C, Tsatsakis AM, Koutedakis Y, Stagos D, Kouretas D and Karathanos V: Effect of a special carbohydrate-protein cake on oxidative stress markers after exhaustive cycling in humans. Food Chem Toxicol 50: 2805-2810, 2012.

11. Kerasioti E, Stagos D, Jamurtas A, Kiskini A, Koutedakis Y, Goutzourelas N, Pournaras S, Tsatsakis AM and Kouretas D: Anti-inflammatory effects of a special carbohydrate-whey protein cake after exhaustive cycling in humans. Food Chem Toxicol 61: 42-46, 2013.

12. Reddy YN, Murthy SV, Krishna DR and Prabhakar MC: Role of free radicals and antioxidants in tuberculosis patients. Indian $\mathrm{J}$ Tuberc 51: 213-218, 2004

13. Spanidis Y, Mpesios A, Stagos D, Goutzourelas N, Bar-Or D, Karapetsa M, Zakynthinos E, Spandidos DA, Tsatsakis AM, Leon G and Kouretas D: Assessment of the redox status in patients with metabolic syndrome and type 2 diabetes reveals great variations. Exp Ther Med 11: 895-903, 2016.

14. Aebi H: Catalase in vitro. Methods Enzymol 105: 121-126, 1984

15. Janaszewska A and Bartosz G: Assay of total antioxidant capacity: Comparison of four methods as applied to human blood plasma. Scand J Clin Lab Invest 62: 231-236, 2002.

16. Keles MS, Taysi S, Sen N, Aksoy H and Akçay F: Effect of corticosteroid therapy on serum and CSF malondialdehyde and antioxidant proteins in multiple sclerosis. Can J Neurol Sci 28: 141-143, 2001

17. Patsoukis N, Zervoudakis G, Panagopoulos NT, Georgiou CD, Angelatou F and Matsokis NA: Thiol redox state (TRS) and oxidative stress in the mouse hippocampus after pentylenetetrazol-induced epileptic seizure. Neurosci Lett 357: 83-86, 2004.

18. Goutzourelas N,Stagos D, Demertzis N, Mavridou P, Karterolioti H, Georgadakis S, Kerasioti E, Aligiannis N, Skaltsounis L, Statiri A, et al: Effects of polyphenolic grape extract on the oxidative status of muscle and endothelial cells. Hum Exp Toxicol 33: 1099-1112, 2014.

19. Goutzourelas N, Stagos D, Housmekeridou A, Karapouliou C, Kerasioti E, Aligiannis N, Skaltsounis AL, Spandidos DA, Tsatsakis AM and Kouretas D: Grape pomace extract exerts antioxidant effects through an increase in GCS levels and GST activity in muscle and endothelial cells. Int J Mol Med 36: 433-441, 2015

20. Priftis A, Stagos D, Konstantinopoulos K, Tsitsimpikou C, Spandidos DA, Tsatsakis AM, Tzatzarakis MN and Kouretas D: Comparison of antioxidant activity between green and roasted coffee beans using molecular methods. Mol Med Rep 12 7293-7302, 2015

21. Kouka P,Priftis A, Stagos D, Angelis A, Stathopoulos P, Xinos N, Skaltsounis AL, Mamoulakis C, Tsatsakis AM, Spandidos DA and Kouretas D: Assessment of the antioxidant activity of an olive oil total polyphenolic fraction and hydroxytyrosol from a Greek Olea europea variety in endothelial cells and myoblasts. Int J Mol Med 40: 703-712, 2017.

22. Makri S, Kafantaris I, Stagos D, Chamokeridou T, Petrotos K, Gerasopoulos K, Mpesios A, Goutzourelas N, Kokkas S, Goulas P, et al: Novel feed including bioactive compounds from winery wastes improved broilers' redox status in blood and tissues of vital organs. Food Chem Toxicol 102: 24-31, 2017.

23. Li YR: Free Radical Biomedicine: Principles, Clinical Correlations, and Methodologies. Bentham Science Publishers, Blacksburg, VA, 2012

24. Sahiner UM, Birben E, Erzurum S, Sackesen C and Kalayci O: Oxidative stress in asthma. World Allergy Organ J 4: 151-158, 2011.

25. Nikitovic D, Corsini E, Kouretas D, Tsatsakis A and Tzanakakis G: ROS-major mediators of extracellular matrix remodeling during tumor progression. Food Chem Toxicol 61: 178-186, 2013.

26. Jenner P: Oxidative stress in Parkinson's disease. Ann Neurol 53 (Suppl 3): S26-S36, discussion S36-S38, 2003.
27. Honda K, Casadesus G, Petersen RB, Perry G and Smith MA: Oxidative stress and redox-active iron in Alzheimer's disease. Ann N Y Acad Sci 1012: 179-182, 2004

28. Dut R, Dizdar EA, Birben E, Sackesen C, Soyer OU, Besler T and Kalayci O: Oxidative stress and its determinants in the airways of children with asthma. Allergy 63: 1605-1609, 2008.

29. Uchida K: Role of reactive aldehyde in cardiovascular diseases. Free Radic Biol Med 28: 1685-1696, 2000.

30. Shoveller AK, Stoll B, Ball RO and Burrin DG: Nutritional and functional importance of intestinal sulfur amino acid metabolism. J Nutr 135: 1609-1612, 2005.

31. Lu SC: Regulation of glutathione synthesis. Mol Aspects Med 30 42-59, 2009.

32. Weydert CJ and Cullen JJ: Measurement of superoxide dismutase, catalase and glutathione peroxidase in cultured cells and tissue. Nat Protoc 5: 51-66, 2010

33. Kim J, Paik HD, Yoon YC and Park E: Whey protein inhibits iron overload-induced oxidative stress in rats. J Nutr Sci Vitaminol (Tokyo) 59: 198-205, 2013.

34. Haraguchi FK, Silva ME, Neves LX, dos Santos RC and Pedrosa ML: Whey protein precludes lipid and protein oxidation and improves body weight gain in resistance-exercised rats. Eur J Nutr 50: 331-339, 2011.

35. Kelly VP, Ellis EM, Manson MM, Chanas SA, Moffat GJ, McLeod R, Judah DJ, Neal GE and Hayes JD: Chemoprevention of aflatoxin B1 hepatocarcinogenesis by coumarin, a natural benzopyrone that is a potent inducer of aflatoxin B1-aldehyde reductase, the glutathione $\mathrm{S}$-transferase $\mathrm{A} 5$ and $\mathrm{P} 1$ subunits, and $\operatorname{NAD}(\mathrm{P}) \mathrm{H}$ :quinone oxidoreductase in rat liver. Cancer Res 60: 957-969, 2000

36. Li J, Lee JM and Johnson JA: Microarray analysis reveals an antioxidant responsive element-driven gene set involved in conferring protection from an oxidative stress-induced apoptosis in IMR-32 cells. J Biol Chem 277: 388-394, 2002.

37. Talalay P, Dinkova-Kostova AT and Holtzclaw WD: Importance of phase 2 gene regulation in protection against electrophile and reactive oxygen toxicity and carcinogenesis. Adv Enzyme Regul 43: 121-134, 2003.

38. Kwak MK, Wakabayashi N, Itoh K, Motohashi H, Yamamoto M and Kensler TW: Modulation of gene expression by cancer chemopreventive dithiolethiones through the Keap1-Nrf2 pathway. Identification of novel gene clusters for cell survival. J Biol Chem 278: 8135-8145, 2003 .

39. Tsuji-Naito K and Jack RW: Concentrated bovine milk whey active proteins facilitate osteogenesis through activation of the JNK-ATF4 pathway. Biosci Biotechnol Biochem 76: 1150-1154, 2012.

40. Scott MD, Lubin BH, Zuo L and Kuypers FA: Erythrocyte defense against hydrogen peroxide: Preeminent importance of catalase. J Lab Clin Med 118: 7-16, 1991.

41. Halliwell B, Clement MV and Long LH: Hydrogen peroxide in the human body. FEBS Lett 486: 10-13, 2000.

42. Tabet F and Touyz RM: Reactive oxygen species, oxidative stress, and vascular biology in hypertension. In: Comprehensive Hypertension. Elsevier, pp337-347, 2007.

43. Ayala A, Muñoz MF and Argüelles S: Lipid peroxidation: Production, metabolism, and signaling mechanisms of malondialdehyde and 4-hydroxy-2-nonenal. Oxid Med Cell Longev 2014: 360438, 2014

44. Sherratt PJ and Hayes JD: Glutathione S-transferases. In: Enzyme Systems that Metabolise Drugs and Other Xenobiotics. Ioannides C (ed). John Wiley \& Sons Ltd., Hoboken, NJ, pp319-352, 2002.

45. Grune T, Reinheckel T and Davies KJA: Degradation of oxidized proteins in mammalian cells. FASEB J 11: 526-534, 1997.

46. Halliwell B and Gutteridge JMC: Chapter 2. In: Free radicals in biology and medicine. 3rd edition. Oxford Science Publications, 1999.

47. Renke J, Popadiuk S, Korzon M, Bugajczyk B and Wozniak M: Protein carbonyl groups' content as a useful clinical marker of antioxidant barrier impairment in plasma of children with juvenile chronic arthritis. Free Radic Biol Med 29: 101-104, 2000 .

48. Levine RL: Carbonyl modified proteins in cellular regulation, aging, and disease. Free Radic Biol Med 32: 790-796, 2002.

49. Lipinski B: Hydroxyl radical and its scavengers in health and disease. Oxid Med Cell Longev 2011: 809696, 2011. 